\title{
Rationality's Confrontation with Irrationality-A Philosophical Thought About Tender Is the Night
}

\author{
Lingmin Zhou ${ }^{1,2}$ \\ ${ }^{1}$ School of Literature, Jinan University, Guangzhou, China \\ ${ }^{2}$ School of Foreign Studies, Southern Medical University, Guangzhou, China \\ Correspondence: Lingmin Zhou, School of Foreign studies, Southern Medical University, No.1023 Shatai Nan \\ Rd, Baiyun District, Guangzhou, China. E-mail: zhoulingsan@163.com
}

Received: November 1, 2018 Accepted: November 13, $2018 \quad$ Online Published: January 30, 2019

doi:10.5539/ass.v15n2p159 URL: https://doi.org/10.5539/ass.v15n2p159

\begin{abstract}
F. Scott Fitzgerald's Tender Is the Night vividly presents us a picture of western world in 1917-1930. In the book, Dick's fall, incestuous behaviors and war's effects on people all show that western world is occupied by irrationality and rationality is confronted with irrationality. This phenomenon arouses us to rethink about western civilization, even human nature and hurries us to best ourselves.
\end{abstract}

Keywords: Tender Is the Night, rationality, irrationality, incest, war

\section{Introduction}

"The modern mentality may be said to have passed through two broad phases-an early modernity and a late modernity" (Perry, 1993, p. 293). In the early stage, formulated during the era of the Scientific Revolution and the Enlightenment, the outlook of early modernity stresses confidence in rationality, science, human goodness. However in the late nineteenth century and early twentieth century the outlook has a shift. Late modern thinkers and scientists achieve revolutionary insights into human nature, the social world, and the physical universe. These developments produce a new outlook. Traditional values are put in doubt; old beliefs are shattered; the Enlightenment view of human rationality is questioned and challenged. Emphasis on irrationality arises. Conflicts between two aspects of human beings-rationality and irrationality inevitably permeate in the western world. Especially in the first half of twentieth century, the conflicts become fiercer and irrationality win the game and has prevailed for several decades. So which side of human nature is more important? Which side should we put emphasis on? Or how do we balance the two sides? And how do we solve the problems caused by irrationality? These questions trouble and confuse many novel writers as well as philosophers. Scott Fitzgerald lives in that period and also has the same concern about human nature and prosperity of human beings. Many of his novels reveal this theme and among them, most obvious is Tender is the Night, which is his last completed novel. This book at first is not well accepted for it's lacking in focus due to its non-chronologicfal plot sequence, but later, people recognize its social value and regard it as "the most wonderful novel of Fitzgerald's" (Wu, 2002:244). This book reflects the intellectual conditions in 1920s and successfully presents the confrontation of rationality and irrationality, arousing us to think about the legacy of western civilization cherished most in the past centuries and posing us the question "where man is to go" and "how to best ourselves".

\section{Dick's Defeat by Irrationality}

Tender is the Night is conditioned in the period of 1917-1930. Dick Diver, the main character of the novel, is a young and promising American psychiatrist. He is handsome and well educated. When he practices his profession in Zurich, he meets a beautiful and wealthy sixteen-year-old mental patient, Nicole Warren, whose madness is caused by incest with her father at the age of 15 . Dick is attracted by Nicole's beauty and regardless of Franz's and Doctor Dohmler"s strong warnings and objection, Dick eventually marries Nicole. After their marriage, they travel extensively and Nicole breaks down from time and time, and Dick devotes all his efforts to cure Nicole so that he neglects his career. On Gausse's beach in French Riviera, Dick meets Rosemary Hoyt, a beautiful seventeen-year-old movie starlet, who instantly falls in love with Dick. Not resisting Rosemary's youth and beauty, Dick is again fond of her and commits adultery with her. With time passing by, Nicole comes to recovery while Dick begins to fall. In the end, they divorce and Nicole marries Tommy Barbarn, leaving Dick 
disappearing into smaller and smaller towns in American. Nick finally meets his destruction, which reflects man's dilemma and tragedy in that period. Although this novel is attacked by many critics when it is published, in 1950s critics began to discuss it as a works far more complex in theme and calculated in narrative structure than had formerly been perceived. "It may be read as an allegory with everyone" and "exams in breadth of the sickness of a society and a culture" (Murphy, 2002, p. 112). The defeat of rationality by irrationality is one of these social traumas, and is fully demonstrated in the novel.

Dick is the man who receives higher education and is taught to embrace science, reason and truth. He is identical with logic of science and strictly practices this principle. Essentially he is a scientific and rational person, who behaves himself intelligently and reasonably. As a young and promising psychiatrist, after all he is not the romantic and imaginary philosopher, but the representative of authority of rationality. His behavior has a kind of logic. Being a scientific researcher, by the aid of science and objective thinking, he is good at observation and analysis. So to some degree, Dick is a symbol of western civilization in the past centuries. In this book, many details show that Dick is a rational person. He works industriously and step by step he finishes his study and obtains the diploma, then sets out to write his first little book: A Psychology for Psychiatrists. Everything is arranged well. He also instructs Nicole man should keep in studying to "get power" (Fitzgerald, 1993, p. 162) (Note 1) and "the work is everything" (161), thinking "it is a confession of weakness for a scientist not to write" (161). When he gets to know Nicole at the beginning, they write letters to each other. Dick gets the information about mental condition of Nicole from these letters so as to make correct diagnosis. So Dick's methods to cure Nicole are accorded with strict process. After marriage, he can control his personal emotion to perform doctor's duty. He can distinguish the mad Nicole from the normal one, and then make records. Everything he has done is based on reason and rationality. In social life he too behaves smartly and calmly like a priest with a cool head. His hardness is meant self-control and self -discipline. He can regulate his passion correctly, regarding self-indulgence as a shame. He handles every detail with careful thoughts. When he deals with the Negro's dead body, he "closed the door and stood thinking" (110), and then "dragged the body quickly into a plausible position in the corridor" (111). So in this book, Dick is originally a typical man with cool and rational minds. However, whatever unique his rationality is, he cannot ward off the evasion of irrationality and eventually meets his destruction, which makes us have to think about irrationality. In the first half of 20th century, "it seemed that reason exercised a very limited influence over human conduct, that impulses, drives, instincts-all forces below the surface-determined behavior much more than did logical consciousness" (Perry, 1993, p. 294). Freud and Jung whose names are mentioned many times in the novel unconsciously do great contribution to the sovereign of irrationality. Rationality which believes that a calculating and analytical reason is supreme arbiter of knowledge and the only path to certainty is challenged by irrationality which emphasizes feeling, spontaneity, instinct, and intuition. Irrationality is so widely applauded that some people took extreme position, bringing great damage to human beings and society as well as western civilization. In this way, Tender is the Night is "a microcosm of the western world in decline". Dick's defeat is clearly illustrated in the book. His rationality can not hold firmly any longer in the period of Jazz Age, in which the value of Dick's rationality is shattered by the unconsciousness, passion and desire. Although Dick is better educated, he is somewhat poor. Although he is cool and scientific, he cannot control his passion in the face of beautiful Nicole. So he marries Nicole to satisfy his material and physical desires. His doctor's strict disciplines give way to his strong desires. His super-ego is "conquered effectively by the disruptible libido-charged impulses of his id and ego" (Murphy, 2002, p. 110). Again, on the beach, he falls in love with young and attractive Rosemary. Dulled by the routine life with Nicole, he commits aborted romance with Rosemary in Rome. Just as Mr. Speers says "(Rosemary) doesn't think; her real depths are Irish and romantic and illogical" (164). She neglects the social moral and bravely expresses her love to marry Dick. The strong emotion can easily occur to her and she takes it for granted. So Rosemary is a completely irrational girl. In the beginning when Dick dates with her, owing to his education and religious belief, he can repress his impulses and behaves gracefully. "The space between heaven and earth had cooled his mind, destroyed the impulsiveness... and make him aware of the too obvious appeal" (38). But he is exhausted by his serious life, and is out of way and commits adultery with Rosemary to relieve himself, so passionate Rosemary captures rational Dick. Thus Dick who is "the last devotee of 19th century's ideas" (Grenberg, 2002, p. 117) is ruined by two women, who symbolize the restless, self-indulgenced and crazy western world. However Dick's experience is not individual but bears border significance. "His past consists of all that we cherish in western civilization. His defeat signifies more than the impossibility of repeating the past. It stands for the defeat of much that was valuable in the culture legacy of the 25 centuries" (Murphy, 2002, p. 113). It stands for the defeat of rationality. 


\section{Incest Motifs -Consciousness Is Conquered by Unconsciousness}

When Fitzgerald was in Maryland working on Tender is the Night in 1932, he sent a note to his friend, Mrs.Baryard Turnbull, thanking her for some "Laurence Items" and said "if one is interested in the world into which willy-nilly one's children will grow up the most accurate data can be found in the European leaders, such as Laurence, Jung, and Spengler..." (Wexelblat, 2010, p. 379). These are great figures in 20th century and strongly believe in "the overwhelming might of the irrational and the appeal of the primitive and, breaking with convention, dealt with sexual themes" (Perry, 1993, p. 334). Obviously Fitzgerald is greatly influenced by them, especially by D.H. Laurence. "Fitzgerald had read D.H. Laurence's Fantasia of the Unconscious around May 1930 and evidently he devoured it with real enthusiasm" (Wexelblat, 2010, p. 379). Without doubt, Fitzgerald would absorb his ideas and naturally put them into his experimental work----Tender is the Night. In Fantasia of the Unconscious, D.H. Laurence gives some description of incest, holding that it is the "higher spiritual love between parents and children" (Wexelblat, 2010, p. 383), which also appears in Tender is the Night and becomes the rudimentary notion in the novel. Freud defines incest like this "a boy's first object choices are always incestuous, focusing on mother and sister; men wish, like the Oedipus, to kill their fathers and marry their mothers; ... (it) a profoundly traumatizing and actual incestuous contact with either parent produces deep psychological scars" (Cokal, 2005, p. 178). "Women, of course, are subject to parallel desires and traumas" (Cokal, 2005, p. 178). According to it, incest can be found everywhere and Fitzgerald makes it organizing motifs of the novel, showing the winning of sub consciousness over consciousness and the defeat of rationality by irrationality.

Nicole's mother dies when she was little and her father takes care of her. Nicole used to come into his father's bed and sleeps with the father. Whenever they go to places in an automobile or a train they used to hold hands. They "were just like lovers" (129). This is a typical incest case which is rudimentary to the structure of the novel. This incestuous experience leaves wounds on Nicole's psychology. She becomes mad and breaks down often. Nicole's madness is the symptom of incest and leads to Dick's destruction. So Nicole's case paves the way for the development of the novel and gives the basic plot to it. At the same time its important place also reveals the domination of unconsciousness in the book. It gives the basic tone to the narration of the novel. Furthermore, besides Nicole's incest, there are many other incestuous indications. Dick falls in love with the young actress Rosemary, whose most famous film is entitled". His relationship with Rosemary also has the tincture of incest. Like Rosemary's father, Dick is of Irish descent and has been an American army doctor, a captain. At dinner party on the Riviera, he speaks to Rosemary with "a lightness seeming to conceal a paternal interest " (28). He calls her "a lovely child" (63) just before kissing her for the first time and in the Paris hotel he says again with a paternal attitude. "When you smile...I always think I'll see a gap where you've lost some baby teeth" (64). Dick is 34, twice Rosemary's age and furthermore Rosemary's immaturity is stressed. When she first appears in 1925, her cheeks suggest "the thrilling flush of children after their cold baths in the evening" (3). "Her body hovered delicately on the last edge of childhood...dew was still on her" (4). Her mother and her are like "prize winning school -children" (4). Dick is partially aware of that Rosemary is only a child and his relationship with her is a bit abnormal. So he "wanted to remove the whole affair from the nursery footing upon which Rosemary persistently established it" (84). But he cannot overcome his passion and realizes that Rosemary "had her hand on the lever more authoratively than he" (85). Helpless as he is, he confesses "when a child can disturb a middle aged gent---things get difficult" (163). He finally tells Nicole that Rosemary is "an infant ...there is a persistent aroma of the nursery" (167). Dick is defeated by immature Rosemary and begins to be on decline. After Rosemary leaves the Riviera, Dick begins to exaggerate the immaturity of other women as well. He is uneasy when Nicole suggests that he dances with a teen-age girl at St.Moritz, and protests "I don't like ickle durls. They smell of castile soap and peppermint, when I dance with them, I feel as if I'm pushing a baby carriage" (172). When he looks at a pretty woman, he thinks "strange children should smiles at each other and say "let's play" (177). Gradually he becomes guilty. When Nicole accuses him, falsely and irrationally, of seducing a patient daughter---"a child, not more than fifteen" (190), he feels guilty. When he is being taken to court after the taxi-driver fight, a crowd beat him, mistaking him for a man who has raped and slain a five-year-old child; Dick cries "I want to make a speech... I want to explain to these people how I raped a five-year-old girl. Maybe I did" (235).

Even Dick's attitude toward his own children is incestuous. In Rome he decides that Rosemary "was young and magnetic, but so was Topsy" (207). When Nicole realizes Dick's love for Rosemary is inspired by "exciting youth", she believes that he draws the same inspiration from the new bodies of his children. Dick once exclaims "what do I care whether Topsy adores me or not? I'm not bringing her up to my wife" (257), assuming that "his love of child does not differ essentially from the love of an adult" (Stanton, 2002:97). He jokes with Lanier about 
"a new law in France that you can divorce a child" (265). Finally, late in the novel Nicole notices his almost unnatural interest in the children. In the end, with all the "incest motifs", Dick is completely destroyed. So to some degree, Dick's fall is in part contributed to the incest. Once again, Dick's rationality is crushed by the incest, which originates in ancient time when impulses and secularization were adored and deeply rooted in human being's innermost part of heart. In a sum, Dick's case is national, as Robert Stanton writes "as the universal popularity of 'Daddy's Girl' suggests, the incest-motif symbolize a worldwide situation" (Stanton, 2002, p. 97). So the significance of Dick's case lies in mirroring the whole world's dilemma and the intellectual crisis in that period.

\section{War - A Symptom of Irrationality}

Fitzgerald is a critical, a philosophical and moral historical novelist, intent on comprehending and explaining in rational terms the motives and implications of human events. In a passage once intended for Tender is the Night, he defines history as "a figured curtain hiding that terrible door into the past through which we must go" (Grenberg, 2002, p. 113). So for Fitzgerald, history for novel serves not only as a topical background but the informing essence. Throughout Tender is the Night, Fitzgerald "interprets history's curtain and takes us through that door to our past" (Grenberg, 2002, p. 117), leading us to walk from World War I to the Great Depression. During this time, war was the most influential element which permeated in every aspect of people's life, so does it in the novel. Fitzgerald not only confines war to the setting but also to the contribution to the theme of the novel. In 20th century, European ideology rises, a new wave of science appears and some philosophers begin to challenge the old values. This period is full of conflicts. Nationalist thinkers with the help of racial and social Darwinist doctrines propagate the subjugation of other peoples. They attack the rational tradition of the Enlightenment and celebrate the primitive, the instinctual and the irrational. Gradually "caution and restrain gave way to belligerency" (Perry, 1993, p. 373). The World War I breaks out. People especially the young look the war as celebration. People in western world all live in the world of irrationality. Reason reaches the point of Nadir. War becomes a token of irrationality, and appears many times in the novel, symbolizing the irrationality's victory over rationality, and leaving both physical and spiritual scars on human beings. Dick begins his relationship with letters. These letters start with reference not to madness but to the military and the war. "I thought when I saw you in your uniform you were so handsome. Then I thought j'e m'en fiche French and German" (121). And though Nicole knows Dick is a doctor. She continues throughout her correspondence to address him as "mon Captaine", "Captain Diver", "Dear Captain Diver" and finally as "Dear Captaine", indicating that Nicole admires Dick more as a captain than a doctor and like others in 1920s worshiping heroes, looks upon Dick as a hero from the war rather a science researcher. The war fairs are also mentioned many times, only to show the war's influence surely exists. At the dinner party, Barban says "I'm a soldier", and "my business is to kill people", showing people are distorted by war. In addition, the war-echoing shots are introduced in the novel. Just as the train whistles and moves, just as Abe waves and Dick responds, "the sound of two revolver shots crashed the narrow air of the platform" (83). And these shots are fired by Maria Wallis, "the young women with the helmet-like hair" (83). Although the war is over, "the shots serve as a remembrances of things past, of the war" (Grenberg, 2002, p. 117). Violence and death are parts of war. In the novel, violence erupts irrationally and persistently. At the party held by Dick, the duel between Tommy and Mckisco is fought; in Rome after Dick dances in a bar in mid-night, conflicts happen between taxi-driver and him, and he is beaten badly and sent to police; when Nicole and Tommy Barban have secret dating in the hotel, two American sailors' fighting arises; Nicole breaks down in bathroom and in the street. Death is also production of the war. Many people die in the novel. Dick's father dies when Dick is with Rosemary; Abe dies in New York; and a Negro dies in Dick's clinic....All these violence and death suggest the turbulence of society and the neurotic trauma of people after the World War I. So war is a symptom signaling the triumph of irrationality.

\section{Conclusion}

Generally, Dick's fall, incestuous behaviors and war's effects on people all show that western world is occupied by irrationality and rationality meets its failure. To avoid the destruction, we must balance them and make modification of human nature. In every sense, Tender is the Night is a successful book. It gives us a picture of the material and spiritual western world and makes us aware of the crazy time of around 1920s. Dick's decline is the decline of western civilization; Dick's failure is the failure of modern society; Dick's tragedy is the whole human being's tragedy. So once again the book presents Fitzgerald's profoundly paradoxical conception that "man's nobility lies in his unyielding efforts to be his best self-even when faced with certain defeat, that man's tragedy lies in his failure to recognize his own limitations and live with them." (Grenberg, 2002, p. 120) 


\section{Acknowledgments}

This study is sponsored by 2014 Annual Planning Project of Philosophy and Social Sciences in Guangdong (GD14CWW009) and 2013 Youth Cultivation Project of Guangdong College of Humanities and Social Science (2013WYM_0007).

\section{References}

Cokal, S. (2005). Caught in the Wrong Story: Psychoanalysis and Narrative Structure in Tender is the Night. Texas Studies in Literature \& Language, 47(1), 75-100. https://doi.org/10.1353/ts1.2005.0005

Fitzgerald, S. (1993). Tender is the Night. New York: Charles Scribner's Sons.

Grenberg, B. L. (2002). Fitzgerald's Figured Curtain: Personality and History in Tender is the Night. Twentieth-Century Literature Criticism, 28. Gale Group Inc.

Murphy, G. D. (2002). The Unconsciousness Dimension of Tender is the Night. Twentieth-Century Literature Criticism, 28. Gale Group Inc.

Perry, M. (1993). An Intellectual History of Modern Europe. Boston: Houghton Mifflin Company.

Stanton, R. (2002). 'Daddy's Girl': Symbol and Theme in Tender is the Night. Twentieth-Century Literature Criticism, 28. Gale Group Inc.

Wexelblat, R. (1987). F. Scott Fitzgerald and D.H. Laurence: Bicycle and Incest. American Literature, 59(3), 378-388. https://doi.org/10.2307/2927122

Wu, J. G. (2002). The Studies about Fitzgerald. Shanghai: Shanghai Foreign Education Press.

\section{Note}

Note 1. Quotation of the novel is from this book and the number of pages are given in the text, so no more notes are made in the following text.

\section{Copyrights}

Copyright for this article is retained by the author(s), with first publication rights granted to the journal.

This is an open-access article distributed under the terms and conditions of the Creative Commons Attribution license (http://creativecommons.org/licenses/by/4.0/). 